\title{
SYMPOSIUM ON NON-STATE ACTORS AND NEW TECHNOLOGIES IN ATROCITY PREVENTION
}

\section{THE JUSTICE AND SECURITY DIALOGUE PROJECT: BUILDING THE RESILIENCE OF NON-STATE ACTORS TO ATROCITY CRIMES}

\author{
Colette Rausch*
}

The doctrine of "responsibility to protect"1 obliges all states to protect populations from "atrocity crimes"namely, genocide, war crimes, crimes against humanity, and ethnic cleansing ${ }^{2}$ — under three "pillars" of protection. Pillar One requires a state to protect its own population from atrocity crimes. ${ }^{3}$ Pillar Two obliges the international community to help states to exercise this responsibility through diplomatic, humanitarian, and other peaceful means. ${ }^{4}$ When both of these approaches fail, states must pursue a "Pillar Three" ${ }^{5}$ strategy: the UN Security Council must "take collective action, in a timely and decisive manner."

This essay examines the atrocity prevention role of the Justice and Security Dialogue Project (JSD) under Pillars One and Two through building the resilience of non-state actors to atrocity crimes. The U.S. Institute of Peace (USIP) and the author supported the project's inception and development in Nepal, and it has been implemented since 2007 in other countries such as Iraq, Libya, and Tanzania. The essay first outlines the obligation on states, under the responsibility to protect, to support the development of critical, societal capacities for atrocity prevention. It then describes the evolution of JSD from its beginnings in Nepal to its current incarnations. It examines the concrete impact of JSD on atrocity prevention, ${ }^{7}$ providing examples of how non-state actors helped defuse local crises that could have led to atrocities. Finally, it explains how tackling two key risk factors for atrocity crimes-a lack of rule of law and limited access to justice—-support the building of societal resilience to atrocities.

\section{Critical Societal Capacities for Atrocity Prevention}

In 2009, the UN Secretary-General issued a report entitled Implementing the Responsibility to Protect ${ }^{8}$ that details the practical strategies to be adopted by member states under each of the three pillars. Two specific Pillar Two recommendations on non-state actors' role in atrocity prevention are important for this essay. First, the report

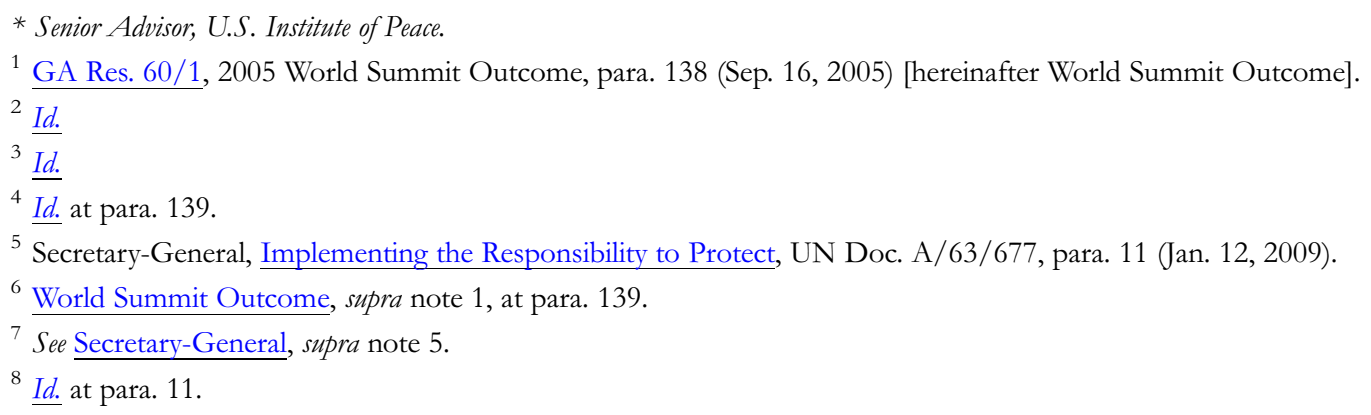

The American Society of International Law and Colette Rausch (C) 2019. This is an Open Access article, distributed under the terms of the Creative Commons Attribution licence (http://creativecommons.org/licenses/by/4.0/), which permits unrestricted re-use, distribution, and reproduction in any medium, provided the original work is properly cited. 
emphasizes the importance of building "critical capacities" (namely, conflict-sensitive development analysis; indigenous mediation capacity; consensus and dialogue; local dispute resolution capacity; and the capacity to replicate capacity) ${ }^{9}$ within societies - in other words, with non-state actors- to prevent atrocities. Second, the report, and the 2014 Framework of Analysis for Atrocity Crimes: A Tool for Prevention, ${ }^{10}$ acknowledges that the promotion of the rule of law, security, and access to justice are complementary paths to "build the resilience of societies to atrocity crimes." 11 The report identifies that "what is most needed, from the perspective of the responsibility to protect, are assistance programmes that are carefully targeted to build specific capacities within societies that would make them less likely to travel the path to crimes that trigger the responsibility to protect." 12 The next section examines one such project, the JSD, and its impact on atrocity prevention through engagement with civil society.

The Genesis and Evolution of JSD

JSD originated in Nepal, when representatives of USIP traveled there in April 2006 amid violent protests provoked by the government's curtailment of civil liberties. Protestors had been injured and killed by security forces and police. Tensions were high. Furthermore, the country was in the tenth year of a civil war-one that led to more than thirteen thousand deaths ${ }^{13}$ — between the monarchical government and a Maoist insurgent group.

Later in 2006, after a period of political agitation and widespread protests, the Nepal government and the United Communist Party of Nepal (Maoist) signed a peace agreement that stripped the king's authorities to rule the country and the Maoists put down their weapons with the intention to enter the political sphere. ${ }^{14}$ Peace and stability seemed within Nepal's grasp. But in 2007, the peace process lost momentum and elections were delayed. Protests and public demonstrations proliferated, a wave of insecurity and lawlessness spread through the country, ${ }^{15}$ and there was a risk of the resurgence of violent conflict.

Against this backdrop, the simple idea emerged of bringing together non-state actors with progressive-minded police to talk with each other. The hope was that once they listened to and heard each other, they could find common ground. Perhaps they could work together to start strengthening justice, security, and the rule of law in Nepal so that the stalled peace process could move forward. USIP supported a dedicated team of Nepali civil society and other non-state actors, who worked with high-ranking police officers to develop a dialogue-based process that evolved into JSD.

USIP and local partners expanded the dialogues from Kathmandu to numerous cities and villages around the country. They also formed a National Focal Group to guide the process. As the dialogue process expanded, USIP established a country office to act as a secretariat. This country office team formed partnerships with local civil society and community-based organizations, with a strict requirement that each partner act inclusively and impartially. ${ }^{16}$

While JSD initially sought to bring civil society actors and police together, the scope of inclusion broadened as time went on. At any given dialogue in the countries in which USIP has established a JSD process, non-state actors

${ }^{9}$ Id. at para. 45.

${ }^{10}$ UN Office on Genocide Prevention and the Responsibility to Protect, Framework OF ANALYsis for Atrocity CRIMES: A TOOL FOR PREVENTION (2014) [hereinafter Framework of Analysis for Atrocity Crimes].

${ }^{11} \underline{I d}$.

12 Secretary-General, supra note 5, at para. 44.

${ }^{13}$ UN Office of the High Commissioner for Human Rights, NePAl Conflict RePort 2012 (2012).

14 The text of the Comprehensive Peace Agreement is in USIP's Peace Agreements Digital Collection.

${ }^{15}$ Nigel Quinney, Justice and Security Dialogue in Nepal: A New Approach to Sustainable Dialogue, 1 Building Peace 11 (2011).

${ }^{16} I$ d. at 23 . 
might include tribal elders, religious leaders, lawyers, journalists, political party representatives, businesspeople, writers, and representatives of minority groups, women's groups, youth groups, former rebels and representatives of local vigilante groups.

The scope of issues addressed during dialogues also expanded over time. JSD provided a forum for members of different ethnic, religious, minority, and sectarian groups to address latent or growing tensions. In some locations where both the police and local populations faced daily violence from armed groups, JSD dialogue mechanisms took root and became a venue where participants could bring information on atrocities and the group could conceive of collective, community responses.

JSD uses the term "dialogue" as an umbrella term to anchor its work but the overall project involves other activities as well. It includes: (1) consensus-building and dialogue; (2) the development of mediation and dispute resolution capacity; (3) the development of indigenous analytical skills, coupled with information gathering and sharing, including about the threat of atrocity crimes; and (4) the development of local projects or initiativesfunded by international partners - to address local challenges identified during the dialogue sessions.

The dialogues went beyond one-off local events. After initially piloting community-based dialogues, the JSD sought to help stakeholders build a formalized, local network and then connect to other networks in their region and country. As the project expanded beyond Nepal to Iraq, Libya, Tanzania, and Yemen in the 2010s, it connected local networks to JSD partners in these other countries, with the aim of sharing experiences and strategies. This is very much in line with the Secretary-General's request to "encourage and support geographically broadbased research networks"17 and to support "a cumulative process of country-to-country"18 and region-to-region learning on atrocity prevention. ${ }^{19}$ In 2019, JSD efforts are under way in Burkina Faso, Mali, Niger, Nigeria, Tunisia, and Senegal. ${ }^{20}$

\section{Building Critical Societal Capacities to Prevent Atrocities}

JSD helps build the "critical capacities within societies that would make them less likely to travel the path to crimes relating to the responsibility to protect." 21 Through dialogue and consensus-building efforts, it connects non-state actors with individuals and groups with whom they have previously had little or no interaction. Over time, a transformation occurs in how religious, ethnic, and other groups perceive one another; dialogue participants move from seeing a "them" and an "us" to seeing a united "we" that works collectively to improve the lives of all community members. Dialogues have helped build trusting relationships and mutual understanding that have in turn provided the foundation for robust and organized local networks that share information, coordinate, and collectively solve problems facing their communities.

As USIP, through its in-country offices, was developing consensus-building and dialogue capacities in the JSD countries, local stakeholders began to grapple with a range of nonlegal issues, including identity-based tensions that could have escalated into atrocity crimes. In Nepal, local non-state religious actors (Muslim, Christian, Buddhist, Sikh, and Hindu) convened to discuss serious ethnic and religious conflicts at the district level, resulting in the establishment of interfaith committees in ten districts across the country. These committees remain active in

\footnotetext{
17 Secretary-General, supra note 5 , at para. 44.

${ }^{18} \underline{I d}$.

${ }^{19} \underline{I d}$.

${ }^{20}$ Justice and Security Dialogues, U.S. Institute of PeAce.

21 Secretary-General, supra note 5, at para. 44.
} 
preventing and resolving religious conflicts today, providing a platform for religious leaders to convene to resolve incidents of religious intolerance before they escalate. ${ }^{22}$

In 2014, when the Islamic State occupied large swaths of Iraq, massive internal displacement took place, especially in the Baghdad, Kirkuk, and Karbala provinces. Sectarian tensions and strained local resources threatened to spark conflict between internally displaced persons (IDPs) and host communities. Local non-state actors addressed this potential threat by inviting IDP representatives to join the JSD process, which addressed misperceptions and fostered collaboration to address national security threats linked to the IDP crisis. Similar scenarios occurred in Zawiya, Libya in 2015, when the expansion of the Islamic State caused an influx of IDPs. The JSD process that already existed in Zawiya became a forum for IDPs to work with local non-state actors and state representatives to diffuse the mounting sectarian tensions between IDPs and the local community.

In addition to fostering societal capacities in consensus and dialogue, JSD has enhanced local mediation and dispute resolution capacity. For example, in Libya, after the 2011 revolution that resulted in the ouster of Muammar Qaddafi, Qaddafi-era justice institutions were discredited. A range of armed militia groups stepped into the vacuum. Community elders and tribal leaders were well placed to resolve disputes but were relatively powerless vis-à-vis the militia groups. Through the JSD process, a diverse group of non-state actors collaborated in Zawiya, developing a code of conduct for local conflict resolution, community reconciliation, and the mediation of disputes that empowered community elders and tribal leaders to serve as the primary mechanism for resolving disputes.

\section{Bolstering the Rule of Law, Security, and Access to Justice to Enbance Societal Resilience to Atrocities}

As the Framework of Analysis for Atrocity Crimes notes, "A State protects its population through the establishment of frameworks and institutions that are guided by the rule of law.... However, when such structures are inadequate or simply do not exist, the ability of the State to prevent atrocity crimes is significantly diminished."23 It also notes that the promotion of rule of law, security, and access to justice are complementary paths to "build the resilience of societies to atrocity crimes." 24

Nepal in 2006-07 did not have the capacity to prevent atrocity crimes. Although parties to the civil war had signed a peace agreement, the state was unable to uphold the rule of law. A police presence was lacking in many areas, particularly rural ones, and trust between police, non-state actors, and local communities was in short supply. As a result, citizens turned to criminal groups for protection. ${ }^{25}$ In one striking example from the hill region, when police responded to an incident, they were tied to lampposts and stoned by local community members. ${ }^{26}$

Non-state actors, in partnership with the police, worked through JSD to strengthen the rule of law, justice, and security. JSD bolstered the state's ability to address atrocity crimes by bringing a variety of resources to state institutions: for instance, the willing partnership of non-state groups in addressing crime and violence and the sharing of information by the local community with the police.

The results of this partnership were striking. In Iraq, for instance, police reported a 75 percent decrease in crime in the three JSD locations within Kirkuk in 2015 and 2016. ${ }^{27}$ In Basra, non-state actors worked with police to

\footnotetext{
${ }^{22}$ Nigel Quinney, Justice and Security Dialogue in Nepal, 2006-17: Innovation, Evolution, and Impact, 5 Building PeACE 39-40, 48 (forthcoming).

${ }^{23}$ Framework of Analysis for Atrocity Crimes, supra note 10, at 3.

${ }^{24} \underline{I d}$.

${ }^{25}$ Quinney, supra note 15, at 12.

${ }^{26}$ Details in author's files.

${ }^{27}$ Sarah Hanssen \& Peter Bauman, Justice and Security Dialogues: Greatest Hits, U.S. InstituTE of PeACE 9 (unpublished internal report, July 2017).
} 
successfully combat drug trafficking, which is closely linked with extremist groups. ${ }^{28}$ In several provinces, JSD has worked with local communities, IDPs, and officials to devise practical steps to avoid potentially widespread violence as IDPs return home to areas liberated from the Islamic State. ${ }^{29}$

JSD has also helped improve access to justice and the protection of vulnerable groups. As a result of policecommunity dialogues in Nepal, the police established police posts and offices in a number of underserved areas and increased patrolling in border areas in several districts. ${ }^{30}$ "Help Desks" and separate women's and children's detention rooms in police stations throughout Nepal help ordinary people to access justice. ${ }^{31}$ JSD initiated a program to bring police officers to schools to explain the duties of both police and citizens; the Nepal Police have since rolled that program out nationwide. ${ }^{32}$

\section{Conclusion}

In his 2017 empirical study of how non-state actors prevented atrocities in Colombia, Oliver Kaplan reached two main findings. First, lower levels of violence are correlated with greater local organizational capacity or the ability to build strong local networks. ${ }^{33}$ Second, strong social cooperation and cohesion are foundational to atrocity prevention because it "becomes more difficult to seed violence through social divisions when civilians are organized and united." ${ }^{34}$ Similar findings have emerged from the JSD experience in places like Nepal, Iraq, and Libya. A significant investment of time, capacity-building efforts, and resources was required to foster robust, local dialogue networks that enhanced shared understanding, trust, mutual respect, and social cohesion. An additional finding from the JSD project was the importance of strong partnerships between civil society and state actors, such as police, prosecutors, and local governments. In the countries where JSD has been operational, neither group could have successfully worked alone.

Rule of law, which has existed since the 1940s as a formalized field, has gone through successive "waves,"35 accompanied by periods of introspection as policy-makers and practitioners grappled with failures in how they delivered assistance. ${ }^{36}$ After eighty years of practice, the rule of law field continues to wrestle with how best to help the rule of law take root and become sustainable. The field is recognizing the importance of nonlegal, nontechnical initiatives such as building social cohesion, organizational capacity, and the ability to undertake dialogue and conflict resolution at the local level. There has also been a conscious strategy, particularly over the past ten to fifteen years, to focus on bottom-up, "legal empowerment" initiatives that see civil society, communities, and individual citizens as central to building the rule of law $^{37}$ and to nurture partnerships between state and non-state actors.

\footnotetext{
${ }^{28}$ Nigel Quinney, Justice and Security Dialogue in Iraq: Enabling Police-Community Collaboration in Perilous Times, 6 BuILDING PEACE 29 (forthcoming).

${ }^{29}$ Id. at $29-30,40$.

${ }^{30}$ Quinney, supra note 22, at 18.

${ }^{31}$ Id. at 49 .

${ }^{32}$ Id. at 50 .

33 Oliver Kaplan, Resisting War 11 (2017).

${ }^{34} \underline{I d}$.

${ }^{35}$ Erik Jensen, The Rule of Law and Judicial Reform: The Political Economy of Diverse Institutional Patterns and Reformer's Responses, in BEYOND Common Knowledge: Empirical Approaches to the Rule of Law (Erik Gilbert Jensen \& Thomas C. Heller eds., 2003).

36 See, e.g., David M. Trubek \& Marc Galanter, Scholars in Self-Estrangement: Some Reflections on the Crisis in Law and Development Studies in the United States, 4 Wis. L. REv. 1062 (1974).

${ }^{37}$ Steven Golub, Beyond the Rule of Law Orthodoxy: The Legal Empowerment Alternative, in Promoting the Rule of Law ABroAD: In SEARCH of KNowledge (Thomas Carothers ed., 2006).
} 
To date, the rule of law community, including the author (until now), has not explicitly looked at its work through the lens of atrocity prevention. Yet rule of law projects like JSD often deliver atrocity prevention outcomes. Looking at facts on the ground through the binary lens of rule of law or atrocity prevention is not helpful, particularly for individuals on the ground for whom this conceptual distinction is irrelevant. Atrocity prevention and rule of law are more related than we think. The rule of law community should look at past and current rule of law initiatives - both their means and outcomes - through the lens of atrocity prevention, and the atrocity field should do the inverse. This would bring both fields closer to each other at the conceptual and operational levels and it could also foster mutual support by integrating state of the art knowledge from each field. 